Cisko L., JUDr., PhD.

SITÁR \& SALOKA, Attorneys at Law

Košice, Slovak Republic

DOI: https://doi.org/10.30525/978-9934-26-064-3-17

\title{
LEGAL REGULATION OF SUSTAINABLE GOVERNANCE OF TRADING COMPANIES IN THE EUROPEAN UNION
}

In this article we focus on the (latest) European Union initiative in the sphere of legal regulation of governance of trading companies in the context of a sustainable environmental protection [1] strategy in the European Economic Area.

In view of the limited scope of this article, we want to approach the relevant legal and also economic aspects in the framework of sustainable corporate governance in the European Union law, including the inspirational impulses from legislation of the Slovak Republic (Member State of the European Union). This issues are a considerably extensive topic and it deserves (from a complex perspective) monographic processing.

In the Company law is ex lege set an obligation within the (statutory) bodies of (individual) companies to act in accordance with the interests of company as a whole. However, from the point of view of the interpretation of the law [2], this obligation, respectively liability is interpreted so as applying (explicitly), so to speak, inside the company, and therefore not against third parties.

For example in a joint-stock company, established under Slovak law, the statutory body is the board of directors, which governs the company's activities and acts on its behalf [3]. In this context, and thus within the governance of the company, is important to state that according to the provision of $\S 194(5)$ first sentence of the Commercial Code, the members of the board of directors are obliged to perform their duties with due care, which includes the obligation to perform them with professional care and in accordance with the interests of the company and all its shareholders. 
The fundamental question to be answered is, to what extent the economic entity should be responsible (according to the nature of its activity) for his actions, having environmental impacts with economic consequences, exempli gratia in a certain region, in which is realized entrepreneurial (industrial) activity.

The European Union initiative aims to ensure that sustainability is further embedded into the corporate governance framework with a view to align better the long-term interests of management, shareholders, stakeholders and society. It aims at improving the framework to incentivize corporate boards to integrate properly stakeholder interests, sustainability risks, dependencies, opportunities and adverse impacts into strategies, decisions and oversight [4, p. 3].

It would serve the following specific objectives: help companies' directors to establish longer-term time horizons in corporate decisionmaking and withstand short-term pressures, strengthen the resilience and long-term performance of companies through sustainable business models and help reducing adverse impacts. It would create legal certainty and level playing field as to the necessary measures to be taken by companies to identify, assess and mitigate adverse impacts in the value chain [4, p. 3].

The intention to protect the environment is the leading idea of European Union [5] and its Member States. One of the modus to realistically implement this protection is a strategy at the national, supranational, equally international level. It's primarily a matter of setting conditions, and that functional and effective systematic legislative solutions, taking into account the achievement of profit of trading companies [6], especially multinational corporations in symbiosis with sustainable entrepreneurship.

This noble activity should be aided by the proclaimed European Union strategy aimed at achieving the sustainability of the European Union, such as the European Green Deal [7, p. 96]. It should be an instrument that should increase the supposed fulfillment objectives [8] in the framework of environmental policy and try to reduce the current (undesirable) situation in the field of the environmental protection. 
At the institutional level of the European Union is currently being discussed the creation of a legal instrument, which would appropriately «roofing» the relevant normative materia to achieve the set objective. In view of the specific type of legal act of the European Union, this should probably be a new directive in the framework of secondary law.

It can be clearly observed that in Company law is beginning to be enforced the policy of (active) participation of the private sector on public affairs, especially in legislation aimed on capital trading companies [9]. The purpose is to achieve public benefit objectives of observance and respect for generally binding legal regulations. In the interest to create appropriate and mainly effective legal regulation of sustainable governance of trading companies, it's certainly a determining framework for implementation of the principles of (not only) commercial law, taking into account the environmental impacts of a permanent nature.

In the framework of de lege ferenda considerations, it would also be possible to consider a certain form of state aid in the form of investment incentives [10] for trading companies that beyond to legal requirements, will realizing their business plan, so to speak abovestandard positive in relation to the (legitimate) public interest. Some suggestions presented in this article are to be understood only in terms of academic opinions and de lege ferenda proposals.

\section{References:}

1. According to the provision of $\S 9$ Act No. 17/1992 Coll. on the environment, environmental protection includes activities that prevents pollution or damage to the environment or such pollution or damage is reduced and eliminated. It includes the protection of its individual components or specific ecosystems and their interrelationships, but also the protection of the environment as a whole.

2. To aspects of interpretation of the law in particular: JÚDA, V.: Teória práva. 2. doplnené a podstatne prepracované vydanie. Belianum. Vydavatel'stvo Univerzity Mateja Bela v Banskej Bystrici. 378 s., 2020, str. 168 a nasl.

3. Under the provision of $\S 191$ (1) first sentence of the Commercial Code - Act. No. 513/1991 Coll. Hereinafter in text referred to as "Commercial Code". 
4. Proposal for legislation fostering more sustainable corporate governance in companies. European Commission, Directorate-General for Justice and Consumers. Ref. Ares (2020) 4034032 - 30/07/2020.

5. Especially see: A Union that strives for more. My agenda for Europe. By President of the European Commission: Ursula von der Leyen. Political Guidelines for the Next European Commission 2019-2024.

6. To the conceptual definition of enterprise see: KUBÍČEK, P.: Pojem podnik z aspektu práva. In: Obchodné spoločnosti - aktuálne otázky a problémy. Plzeň: Aleš Čeněk, 2008, str. 103 a nasl.

7. Communication from the Commission to the European Parliament, the European Council, the Council, the European Economic and Social Committee and the Committee of the Regions. The European Green Deal. COM/2019/640 final. European Commission. Done at Brussels, 11 December 2019. Hereinafter in text referred to as "European Green Deal". At this place, we want to point out that the power of the European Commission's legislative initiative doesn't extended only to the procedural aspects (to the right to submit a proposal for a legal act), but also in a material context that is to have the right to determine its content. In: JÚDA, V.: Rozsah a limity právomoci Komisie pri prijímaní záväzných právnych aktov Únie. In: FINĎOVÁ, E. (ed.): Nové trendy v práve I. Zborník príspevkov z medzinárodnej vedeckej konferencie konanej 7. - 8. apríla 2016 na Právnickej fakulte Univerzity Mateja Bela v Banskej Bystrici. Právnická fakulta Univerzity Mateja Bela v Banskej Bystrici. Banská Bystrica, Belianum, 2016.

8. See the Annex to the European Green Deal and therefore a plan of key measures including the timeframes, to be implemented in the coming period. Within the thematic focus of this article, see for example: Mainstreaming sustainability in all European Union policies; Industrial strategy of the European Union etc.

9. To the rights of shareholders in a joint-stock company e. g. see: Consolidated text: Directive 2007/36/EC of the European Parliament and of the Council of 11 July 2007 on the exercise of certain rights of shareholders in listed companies. Done at Strasbourg, 11 July 2007. Also: Consolidated text: Directive (EU) 2017/1132 of the European Parliament and of the Council of 14 June 2017 relating to certain aspects of company law (codification). Text with EEA relevance. Done at Strasbourg, 14 June 2017. To the commercial and legal aspects in the sphere of entrepreneurial activities of legal persons, see in this context: ĎURICA, M.: Obchodné spoločnosti: $§ 56-68$ (okrem § 66a, 66b). In: Obchodný zákonník: Komentár. 4. aktualizované vydanie. Bratislava: C.H. Beck, 2013, str. 209 a nasl.

10. To commercial legal obligations in investment banking and to financial and

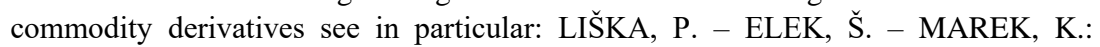
Bankovní obchody. Wolters Kluwer, 216 s., 2014. To this issues also: KUBINEC, M.: Základy práva proti nekalej sút’aži. Vysokoškolská učebnica. 1. vydanie. Banská Bystrica: Vydavatel'stvo Univerzity Mateja Bela. Belianum. 2018, 164 s. 